\title{
Why do players buy in-game content? An empirical study on concrete purchase motivations
}

Juho Hamari *

Game Research Lab, School of Sciences, University of Tampere FIN-33014 University of Tampere, Finland

tel: +358503186861

email: juho.hamari@uta.fi

Kati Alha

Game Research Lab, School of Sciences, University of Tampere email: kati.alha@uta.fi

\section{Simo Järvelä}

Department of Information and Service Economy, School of Business, Aalto University email: simo.jarvela2@aalto.fi

\section{J. Matias Kivikangas}

Department of Information and Service Economy, School of Business, Aalto University email: matias.kivikangas@aalto.fi

\section{Jonna Koivisto}

Game Research Lab, School of Sciences, University of Tampere email: lauri.keronen@uta.fi

\section{Janne Paavilainen}

Game Research Lab, School of Sciences, University of Tampere email: janne.paavilainen@uta.fi

\footnotetext{
* Corresponding author
} 


\begin{abstract}
Selling in-game content has become a popular revenue model for game publishers. While prior research has investigated latent motivations as determinants of in-game content purchases, the prior literature has not focused on more concrete reasons to purchase in-game content that stem from how the games are being designed. We form an inventory of reasons (19) to buy in-game content via triangulating from analyses of top-grossing free-to-play games, from a review of existing research, and from industry expert input. These reasons were operationalized into a survey $(\mathrm{N}=519)$. Firstly, we explored how these motivations converged into categories. The results indicated that the purchasing reasons converged into six dimensions: 1) Unobstructed play, 2) Social interaction, 3) Competition, 4) Economical rationale, 5) Indulging the children, and 6) Unlocking content. Secondly, we investigated the relationship between these factors and how much players spend money on in-game content. The results revealed that the purchase motivations of unobstructed play, social interaction, and economical rationale were positively associated with how much money players spend on in-game content. The results indeed imply that the way designers implement artificial limitation and obstacles as well as social interaction affects how much players spend money on in-game content.
\end{abstract}

Keywords: free-to-play; freemium; online games; social networking services; video games; virtual goods 


\section{Introduction}

Virtual goods and other forms of in-game content have rapidly become one of the biggest forms of online consumption for gamers and de facto revenue model for game publishers (Alha et al. 2016; Hamari 2015; Lehdonvirta 2009). Selling virtual goods has especially been an integral part of the free-to-play/freemium business model that has rapidly spread to online services in general but perhaps most prominently to online games. In the free-to-play model the core game is offered for free for the user in order to acquire as many users as possible. The game publisher then attempts to upsell various pieces of in-game content in order to generate revenue. For instance, an analysis of the top 300 apps in the Apple's App Store reveals that the majority of downloadable apps are games that employ the free-to-play model (Brockmann et al. 2015).

One of the main consequences of selling in-game content has been its impact on the design philosophy of games (Hamari \& Lehdonvirta 2010; Hamari 2011; Lin \& Sun 2011; Nieborg 2015). Developers are no longer simply trying to create the best possible game they can in the artistic sense but rather, in order to sell in-game content, the game developers attempt to craft the game in a way that it would entice users to purchase in-game content as frequently as possible. This can be done by tweaking the game according to player behavior and introducing new content periodically (Alves \& Roque 2007; Hamari 2011; Hamari \& Lehdonvirta 2010; Hamari \& Järvinen 2011; Nieborg 2015; Oh \& Ryu 2007). Therefore, purchase decisions for in-game content are not only affected by people's general attitudes, consumption values, and motivations but also by the design decisions and the needs built into the game by the developers (Alha et al. 2014; Hamari 2010; Hamari \& Lehdonvirta 2010; Hamari \& Keronen 2016; Hamari \& Järvinen 2011; Harviainen \& Hamari, 2015; Lin \& Sun 2011; Paavilainen et al. 2013). 
While there has been a clear increase in studies investigating purchases of in-game content and virtual goods during the last decade (see e.g. Hamari \& Keronen 2016 for a review), the related quantitative literature has commonly focused on more abstract psychological constructs rather than being concerned with possible purchase motivations that stem from how the game has been designed. This vein of literature has been interested in predicting virtual good or in-game content (re-)purchases from perspectives of different affective experiences in the game (Chou \& Kimsuwan 2013; Hamari 2015; Lee et al. 2012; Luo et al. 2011), customer lifetime value (Hanner \& Zarnekov 2015), content visibility (Jankowski et al. 2016), cultural and demographic aspects (Lee \& Wohn 2012; Wohn 2014), tele/social presence (Animesh et al. 2011), playfulness (Han \& Windsor 2013), flow/cognitive involvement (Huang 2012; Liu \& Shiue 2014), transaction cost theory (Guo \& Barnes 2011; 2012), satisfaction (Kim 2012), perceived value (Chou \& Kimsuwan 2013; Park \& Lee 2011), critical reception (Alha et al. 2016), technology acceptance (Cha 2011; Domina et al. 2012; Hamari \& Keronen 2016), theories of planned behavior and reasoned action (Gao 2014; Kaburuan et al. 2009), and expectancy-disconfirmation model (Wang \& Chang 2013; 2014). Qualitative efforts mapping the phenomenon, on the other hand, have been more successful in identifying concrete purchase motivations that pertain to the nature of the business models and its related effect on game design (Hamari \& Lehdonvirta 2010; Hamari 2011; Hamari \& Järvinen 2011; Zagal et al. 2013), user experiences (Alha et al. 2014; Cleghorn \& Griffiths 2015; Lin \& Sun 2011; Paavilainen et al. 2013), and features of virtual goods (Lehdonvirta 2009). While the quantitative body of literature has focused on relatively abstract psychological factors, and has therefore been unable to provide knowledge on more specific reasons for purchases that stem from how the game is designed, the contributions of the qualitative studies sphere, on the other hand, have not yet been harnessed in quantitative 
efforts to systematize the measurement and understanding of purchase motivators for in-game content. Therefore, the efforts on measuring purchase motivations stemming from the design of the game are currently lacking.

To this end, we aim to investigate reasons for purchasing in-game content that stem from the experiences, obstacles, and inconveniences in the game. Firstly, we form a measurement instrument for measuring the different reasons for buying in-game content by triangulating the findings of analyzing top-grossing free-to-play games, existing research on purchase motivations, in-depth discussions with game industry specialists, and literature related to gaming motivations. The resulting inventory of reasons (19) to buy in-game content was operationalized into a survey and was administered to free-to-play game players $(\mathrm{N}=519)$ that had purchased ingame content. Next, the factorial properties of the measurement instrument are investigated. Finally, we investigate which purchase motivation factors predict how much players spend real money on in-game content.

\section{Questionnaire development}

We developed a set of items corresponding to reasons for making purchases in free-to-play games. The aim was to focus on concrete reasons for buying in-game content that players are faced with in free-to-play games rather than more abstract psychological factors as has been the case with the related literature thus far. To comprise a comprehensive list, we analyzed one hundred top-grossing free-to-play games (excluding casino games) according to AppAnnie (a prominent data analysis tool used in mobile markets). From each genre, the typical in-app purchases and in-game spending mechanics were analyzed. We then triangulated the findings based on empirical knowledge on game content business (Alha et al. 2014; Evans 2015; Hamari 
\& Lehdonvirta 2010; Hamari 2011; Hamari \& Järvinen 2011; Kallio et al. 2010; Lehdonvirta

2009; Lin \& Sun 2011; Oh \& Ryu 2007; Nieborg 2015; Paavilainen et al. 2013; 2015a; 2015b;

Tyni et al. 2011), and on gaming motivations (Hamari et al. 2015; Sherry et al. 2006; Yee 2006;

Ryan et al. 2006), supported by a plethora of discussion amidst game developers during the last

eight years. The resulting list was further discussed, evaluated and edited in collaboration with an

industry specialist who is in charge of monetization strategies in a major free-to-play games

company. The final list of 19 motivations was included in a survey (See Table 1).

In the survey, the respondents were instructed to consider all the occasions of using money on ingame content and asked to rate how important the following reasons had been when making ingame purchases on a 7-point Likert scale $(1=$ Not at all important, $7=$ Extremely important $)$.

Table 1: Reasons to purchase in-game content

\begin{tabular}{|l|l|l|l|}
\hline \multicolumn{1}{|c|}{ Motivation } & \multicolumn{1}{|c|}{ Statement } & \multicolumn{1}{c|}{ Description } & $\begin{array}{l}\text { Literature that discusses the } \\
\text { phenomenon (in addition to the } \\
\text { industry specialist } \\
\text { recommendations) }\end{array}$ \\
\hline Avoiding spam & $\begin{array}{l}\text { I didn't want to } \\
\text { bother others by } \\
\text { spamming them. }\end{array}$ & $\begin{array}{l}\text { Many free-to-play games have provided } \\
\text { the possibility for players to earn in- } \\
\text { game currency or goods by sending } \\
\text { messages to friends. Spamming friends } \\
\text { in this manner, however, is generally } \\
\text { frowned upon. Therefore, some players } \\
\text { rather pay up than spam their friends. }\end{array}$ & $\begin{array}{l}\text { Alha et al 2014; Paavilainen et al. } \\
\text { 2015b; Paavilainen et al. 2013 } \\
\text { (spamming is considered as a major } \\
\text { inconvenience in game design); } \\
\text { Nieborg 2015 (paying is an } \\
\text { alternative to asking friends to } \\
\text { help) }\end{array}$ \\
\hline $\begin{array}{l}\text { Becoming the } \\
\text { best }\end{array}$ & $\begin{array}{l}\text { I wanted to be } \\
\text { the best in the } \\
\text { game. }\end{array}$ & $\begin{array}{l}\text { Many in-game items boost the } \\
\text { performance of players thus giving } \\
\text { them an advantage over other players. }\end{array}$ & $\begin{array}{l}\text { Alha et al. 2014 (getting an edge } \\
\text { over other players); Lehdonvirta } \\
\text { 2009 (performance \& winning); } \\
\text { Yee 2006 (achievement); Ryan et } \\
\text { al. 2006 (competence); Tyni et al. } \\
\text { 2011 (competition); Nieborg 2015; } \\
\text { Evans 2015; Park \& Lee 2011 } \\
\text { (character competency) }\end{array}$ \\
\hline Continuing play & $\begin{array}{l}\text { I wanted to } \\
\text { continue the } \\
\text { game. }\end{array}$ & $\begin{array}{l}\text { Many free-to-play game designs } \\
\text { prevent player from continuing the } \\
\text { game sessions unless they use real } \\
\text { money. }\end{array}$ & $\begin{array}{l}\text { Hamari \& Lehdonvirta 2010 (the } \\
\text { need to purchase new items when } \\
\text { progressing); Paavilainen et al. } \\
\text { 2015a, Paavilainen et al. 2013 } \\
\text { (paywalls) }\end{array}$ \\
\hline
\end{tabular}




\begin{tabular}{|c|c|c|c|}
\hline Giving gifts & $\begin{array}{l}\text { I wanted to give } \\
\text { gifts to others. }\end{array}$ & $\begin{array}{l}\text { Free-to-play games sell gifts that can be } \\
\text { given to other players. }\end{array}$ & $\begin{array}{l}\text { Lehdonvirta 2009; Hamari \& } \\
\text { Järvinen 2011; Paavilainen et al. } \\
2016\end{array}$ \\
\hline $\begin{array}{l}\text { Investing in a } \\
\text { hobby }\end{array}$ & $\begin{array}{l}\text { I wanted to } \\
\text { invest in my } \\
\text { gaming hobby. }\end{array}$ & $\begin{array}{l}\text { The gaming activity can be considered } \\
\text { as a hobby similar to any other free- } \\
\text { time activity. Players may be motivated } \\
\text { to invest financially to their hobby in } \\
\text { addition to investing time. }\end{array}$ & $\begin{array}{l}\text { Alha et al. } 2014 \text { (free-to-play } \\
\text { games can be compared to other } \\
\text { hobbies that cost money) }\end{array}$ \\
\hline $\begin{array}{l}\text { Indulging the } \\
\text { children }\end{array}$ & $\begin{array}{l}\text { I wanted to make } \\
\text { my kids happy. }\end{array}$ & $\begin{array}{l}\text { Games are played with young children, } \\
\text { or given to older children to be played, } \\
\text { both in order to entertain them and to } \\
\text { buy free time for the parents. To } \\
\text { support those goals, parents may } \\
\text { sometimes need to make purchases. The } \\
\text { children have their own motivations for } \\
\text { gaining the content, but the parents } \\
\text { control the money. }\end{array}$ & Kallio et al. 2010 \\
\hline Personalization & $\begin{array}{l}\text { I wanted to } \\
\text { personalize my } \\
\text { characters, the } \\
\text { things I build etc. }\end{array}$ & $\begin{array}{l}\text { One prominent value proposition of a } \\
\text { lot of in-game content is that it affords } \\
\text { players to differentiate themselves from } \\
\text { other players by personalizing their } \\
\text { avatar or other belonging in-game. }\end{array}$ & $\begin{array}{l}\text { Lehdonvirta } 2009 \text { (customizability; } \\
\text { provenance); Tyni et al. } 2011 \\
\text { (customization) }\end{array}$ \\
\hline $\begin{array}{l}\text { Playing with } \\
\text { friends }\end{array}$ & $\begin{array}{l}\text { I wanted to play } \\
\text { with my friends. }\end{array}$ & $\begin{array}{l}\text { Some free-to-play games require } \\
\text { players to use real money in order to } \\
\text { add more friends in-game, or employ } \\
\text { highly desired features that must be } \\
\text { purchased if one wants to play with } \\
\text { their friends. }\end{array}$ & $\begin{array}{l}\text { Hamari \& Järvinen 2011; Yee } 2006 \\
\text { (sociality); Ryan et al. } 2006 \\
\text { (relatedness) }\end{array}$ \\
\hline $\begin{array}{l}\text { Protecting } \\
\text { achievements }\end{array}$ & $\begin{array}{l}\text { I wanted to } \\
\text { protect stuff I } \\
\text { had already } \\
\text { earned in the } \\
\text { game. }\end{array}$ & $\begin{array}{l}\text { Item/achievement degradation is a } \\
\text { prominent game design pattern in free- } \\
\text { to-play games where players' earned } \\
\text { achievement or items may degrade or } \\
\text { be threatened if they are not protected. }\end{array}$ & $\begin{array}{l}\text { Hamari \& Lehdonvirta 2010; } \\
\text { Hamari 2011; Hamari \& Järvinen } \\
2011\end{array}$ \\
\hline $\begin{array}{l}\text { Reaching } \\
\text { completion }\end{array}$ & $\begin{array}{l}\text { I wanted to } \\
\text { complete a } \\
\text { level/building } \\
\text { etc. }\end{array}$ & $\begin{array}{l}\text { Completing different tasks and levels } \\
\text { etc. in a game can be too difficult or } \\
\text { time consuming. Therefore, some } \\
\text { players might be willing to pay for } \\
\text { skipping parts of the game. }\end{array}$ & $\begin{array}{l}\text { Hamari 2011; Hamari \& Järvinen } \\
\text { 2011; Ryan et al. } 2006 \\
\text { (competence); Yee } 2006 \\
\text { (achievement); Tyni et al. } 2011 \\
\text { (energy refills and task } \\
\text { completions) }\end{array}$ \\
\hline $\begin{array}{l}\text { Reasonable } \\
\text { pricing }\end{array}$ & $\begin{array}{l}\text { The free-to-play } \\
\text { game was } \\
\text { reasonably } \\
\text { priced. }\end{array}$ & $\begin{array}{l}\text { Simply, players may be enticed to } \\
\text { purchase in-game content if they } \\
\text { perceive the deals to be cheap. }\end{array}$ & $\begin{array}{l}\text { Hamari \& Järvinen 2011; Park \& } \\
\text { Lee } 2011 \text { (monetary value) }\end{array}$ \\
\hline $\begin{array}{l}\text { Avoiding } \\
\text { repetition }\end{array}$ & $\begin{array}{l}\text { I didn't want to } \\
\text { spend time } \\
\text { repeating same } \\
\text { tasks over and } \\
\text { over again. }\end{array}$ & $\begin{array}{l}\text { Many games have been criticized for } \\
\text { repetitive content. Since designing } \\
\text { repetitive content is less costly and } \\
\text { requires less innovation it is commonly } \\
\text { used. "Grinding" repetitive content can, }\end{array}$ & $\begin{array}{l}\text { Hamari \& Lehdonvirta } 2010 \\
\text { (intentional inconvenient design); } \\
\text { Evans 2015; Paavilainen et al. } \\
2015 b\end{array}$ \\
\hline
\end{tabular}




\begin{tabular}{|c|c|c|c|}
\hline & & $\begin{array}{l}\text { however, be boring for the players, and } \\
\text { therefore, players may be enticed to use } \\
\text { real money in order to take a shortcut. }\end{array}$ & \\
\hline $\begin{array}{l}\text { Showing off } \\
\text { achievements }\end{array}$ & $\begin{array}{l}\text { I wanted to show } \\
\text { off my } \\
\text { achievements in } \\
\text { the game. }\end{array}$ & \multirow{2}{*}{$\begin{array}{l}\text { Players unlock, earn and win many } \\
\text { notable signifiers of achievement in } \\
\text { games (such as trophies, badges and } \\
\text { other virtual goods). However, being } \\
\text { able to display all this gaming capital } \\
\text { has been also harnessed as a revenue } \\
\text { source. Social representativeness and } \\
\text { showing off have been observed to be a } \\
\text { major reason for in-game content } \\
\text { purchases. }\end{array}$} & \multirow[t]{2}{*}{$\begin{array}{l}\text { Lehdonvirta } 2009 \text { (provenance); } \\
\text { Sherry et al. 2006; Tyni et al. 2011; } \\
\text { Park \& Lee } 2011 \text { (visual authority) }\end{array}$} \\
\hline $\begin{array}{l}\text { Showing off to } \\
\text { friends }\end{array}$ & $\begin{array}{l}\text { I wanted to show } \\
\text { off to my friends. }\end{array}$ & & \\
\hline $\begin{array}{l}\text { Participating in } \\
\text { a special event }\end{array}$ & $\begin{array}{l}\text { I wanted to } \\
\text { participate in } \\
\text { special events. }\end{array}$ & $\begin{array}{l}\text { Game companies attempt to come up } \\
\text { with novel events and content in the } \\
\text { game to keep it fresh. This has also } \\
\text { been one way for game companies to } \\
\text { introduce new purchasable content. } \\
\text { Moreover, special events are often } \\
\text { perceived as unique one-off events, } \\
\text { which may induce perceived rarity and, } \\
\text { therefore, fear of missing out }\end{array}$ & $\begin{array}{l}\text { Hamari \& Lehdonvirta 2010; } \\
\text { Lehdonvirta 2009; Tyni et al. } 2011\end{array}$ \\
\hline Special offer & $\begin{array}{l}\text { I wanted to buy } \\
\text { special offers } \\
\text { that give me } \\
\text { more value. }\end{array}$ & $\begin{array}{l}\text { Simply, players may be enticed to } \\
\text { purchase in-game content if they } \\
\text { perceive the deals to be cheap. This } \\
\text { may especially be the case if there are } \\
\text { special offers of limited quantity or for } \\
\text { limited amount of time. }\end{array}$ & $\begin{array}{l}\text { Hamari \& Järvinen 2011; Tyni et } \\
\text { al. 2011; Evans } 2015\end{array}$ \\
\hline Speeding timers & $\begin{array}{l}\text { I wanted to speed } \\
\text { up timers. }\end{array}$ & $\begin{array}{l}\text { Many games set artificial timers as to } \\
\text { how long it takes to, for example, build } \\
\text { a building into the player's village. } \\
\text { Many players wish to make this process } \\
\text { quicker. }\end{array}$ & $\begin{array}{l}\text { Hamari \& Lehdonvirta } 2010 \\
\text { (intentional inconvenient design); } \\
\text { Lehdonvirta } 2009 \text { (speeding } \\
\text { gameplay); Tyni et al. } 2011 \\
\text { (energy refills and task } \\
\text { completions); Nieborg 2015; Evans } \\
2015\end{array}$ \\
\hline $\begin{array}{l}\text { Supporting a } \\
\text { good game }\end{array}$ & $\begin{array}{l}\text { I wanted to } \\
\text { support a free-to- } \\
\text { play game that is } \\
\text { good. }\end{array}$ & $\begin{array}{l}\text { Players might be enticed to spend } \\
\text { money on in-game content to support } \\
\text { the company running the game and thus } \\
\text { ensuring the game's continuance }\end{array}$ & Alha et al. 2014 \\
\hline $\begin{array}{l}\text { Unlocking } \\
\text { content }\end{array}$ & $\begin{array}{l}\text { I wanted to open } \\
\text { new playable } \\
\text { content (e.g. } \\
\text { levels, } \\
\text { characters, } \\
\text { cards...). }\end{array}$ & $\begin{array}{l}\text { One major form of in-game content is } \\
\text { simply more content to play such as } \\
\text { maps and levels. }\end{array}$ & $\begin{array}{l}\text { Hamari \& Lehdonvirta 2010; } \\
\text { Nieborg 2015; Evans } 2015\end{array}$ \\
\hline
\end{tabular}




\section{Data}

The data was gathered by an online survey through websites and social media pages of three major Finnish games-related magazines. The link to the survey was posted on the websites and in some cases also on the Facebook pages of the magazines. In all cases, the link was accompanied by a short introduction and invitation to participate in the study. The survey was active for 17 days. All the respondents who entered their contact information at the end of the survey were entered in a prize raffle of three video games and eight movie tickets. During the timeframe of the survey, 1159 responses were collected.

From the collected sample of 1159,70 cases reported not to have played free-to-play games, and were therefore removed. For the remaining responses, analyses were conducted for detecting outliers. For the purposes of this study, only the respondents that had bought in-game content were retained in the final data set as only they were able to respondent to the respective questions concerning purchase reasons. This resulted in a sample of 519 respondents.

Table 2 outlines the demographic details of the respondents. The gender distribution of the data is unequal with male respondents representing over $91 \%$ of the sample. Regarding age, most respondents, specifically $94.8 \%$, are under 40 years of age. Of the under 40 -year-olds, the 20 to 29-year-olds are most heavily represented. The gender and age division most likely reflect the readership of the channels for recruiting the respondents, the Finnish gaming magazines. The respondents report to be mostly students. The highest completed level of education reveals that most respondents report to have either a secondary level or a higher education. Moreover, given the high percentage of students in the sample, the heavy representation of respondents reporting their yearly household income to be below $19999 €$ is reasonable. 
Table 2: Demographic information of respondents, including gender, age, employment, education, and income.

\begin{tabular}{|c|c|c|c|c|c|}
\hline Gender & $\mathbf{N}$ & $\%$ & Education & $\mathbf{N}$ & $\%$ \\
\hline Female & 41 & 7.9 & No education & 6 & 1.2 \\
\hline Male & 475 & 91.5 & Basic education & 102 & 19.7 \\
\hline \multirow[t]{2}{*}{ Other } & 3 & 0.6 & Secondary level education & 274 & 52.8 \\
\hline & & & Higher education & 137 & 26.4 \\
\hline \multicolumn{6}{|l|}{ Age } \\
\hline-19 & 120 & 23.1 & Household income $€$ & & \\
\hline $20-29$ & 244 & 47.0 & -19999 & 217 & 41.8 \\
\hline $30-39$ & 128 & 24.7 & $20000-39999$ & 114 & 22.0 \\
\hline \multirow[t]{2}{*}{$40-49$} & 27 & 5.2 & $40000-59999$ & 84 & 16.2 \\
\hline & & & $60000-79999$ & 62 & 11.9 \\
\hline Employment & & & $80000-99999$ & 20 & 3.9 \\
\hline Full time employment & 149 & 28.7 & 100 000-119999 & 15 & 2.9 \\
\hline Part time employment & 14 & 2.7 & 120 000-139999 & 3 & 0.6 \\
\hline Student & 232 & 44.7 & $140000-$ & 4 & 0.8 \\
\hline Unemployed & 97 & 18.7 & & & \\
\hline Retired & 4 & 0.8 & & & \\
\hline Other & 23 & 4.4 & & & \\
\hline
\end{tabular}

\subsection{Descriptive statistics}

A descriptive analysis (Table 3$)$ of the purchase motivations reveal that unlocking content $(\mathrm{M}=$ 4.963) was reported as the most important reason on average, followed by supporting a good game $(M=4.765)$, reasonable pricing $(M=4.127)$, special offers $(M=3.809)$, and investing in a hobby $(\mathrm{M}=3.441)$. These top motivations seem to correspond mostly to economical extraneous reasons for purchasing in-game content rather than to specific situations in the game, and therefore, possibly these reasons can apply to more players than more specific reasons and 
thus show higher overall means. Moreover, unlocking content does not refer to any type of content and could apply to a variety of in-game content and also therefore exhibit an elevated mean. From the more specific in-game related reasons to purchase we can see higher variability in means that, however, all fall below the mean of the scale (4): personalization $(\mathrm{M}=3.672)$, speeding timers $(\mathrm{M}=3.206)$, continuing play $(\mathrm{M}=3.019)$, avoiding repetition $(\mathrm{M}=2.715)$, playing with friends $(\mathrm{M}=2.671)$, reaching completion $(\mathrm{M}=2.414)$, giving gifts $(\mathrm{M}=2.387)$, avoiding spam $(\mathrm{M}=2.329)$, participating in a special event $(\mathrm{M}=2.229)$, becoming the best $(\mathrm{M}$ $=2.208)$, protecting achievements $(\mathrm{M}=1.861)$, showing off achievements $(\mathrm{M}=1.855)$, showing off to friends $(\mathrm{M}=1.584)$ and indulging the children $(\mathrm{M}=1.297)$.

Table 3: Descriptive statistics

\begin{tabular}{|c|c|c|c|c|c|c|c|c|c|c|}
\hline & $\begin{array}{l}\text { Showing } \\
\text { off to } \\
\text { friends } \\
\end{array}$ & $\begin{array}{l}\text { Showing } \\
\text { off } \\
\text { achievem } \\
\text { ents } \\
\end{array}$ & $\begin{array}{l}\text { Giving } \\
\text { gifts }\end{array}$ & $\begin{array}{l}\text { Personali } \\
\text { zation } \\
\end{array}$ & $\begin{array}{l}\text { Becomin } \\
\text { g the best }\end{array}$ & $\begin{array}{l}\text { Playing } \\
\text { with } \\
\text { friends }\end{array}$ & $\begin{array}{l}\text { Avoiding } \\
\text { spam }\end{array}$ & $\begin{array}{l}\text { Unlockin } \\
\text { g content }\end{array}$ & $\begin{array}{l}\text { Speeding } \\
\text { timers }\end{array}$ & $\begin{array}{l}\text { Avoiding } \\
\text { repetitio } \\
\text { n }\end{array}$ \\
\hline Mean & 1.584 & 1.855 & 2.387 & 3.672 & 2.208 & 2.671 & 2.329 & 4.963 & 3.206 & 2.715 \\
\hline \multirow[t]{2}{*}{ Std. Dev. } & 1.205 & 1.460 & 1.924 & 2.282 & 1.672 & 2.085 & 2.026 & 2.070 & 2.259 & 2.087 \\
\hline & $\begin{array}{l}\text { Continui } \\
\text { ng play }\end{array}$ & $\begin{array}{l}\text { Reaching } \\
\text { completi } \\
\text { on }\end{array}$ & $\begin{array}{l}\text { Participa } \\
\text { ting in a } \\
\text { special } \\
\text { event }\end{array}$ & $\begin{array}{l}\text { Protectin } \\
\text { g } \\
\text { achievem } \\
\text { ents }\end{array}$ & $\begin{array}{l}\text { Reasonab } \\
\text { le pricing }\end{array}$ & $\begin{array}{l}\text { Special } \\
\text { offers }\end{array}$ & $\begin{array}{l}\text { Indulgin } \\
\text { g the } \\
\text { children } \\
\end{array}$ & $\begin{array}{l}\text { Supporti } \\
\text { ng a good } \\
\text { game }\end{array}$ & $\begin{array}{l}\text { Investing } \\
\text { in a } \\
\text { hobby }\end{array}$ & \\
\hline Mean & 3.019 & 2.414 & 2.229 & 1.861 & 4.127 & 3.809 & 1.297 & 4.763 & 3.441 & \\
\hline Std. Dev. & 2.242 & 2.056 & 1.835 & 1.606 & 2.041 & 2.285 & 1.012 & 2.172 & 2.133 & \\
\hline
\end{tabular}

\section{Factor analyses}

\subsection{Exploratory factor analysis}

We conducted an exploratory factor analysis using the PCA extraction method and the Varimax rotation. The factorial structure converged in 11 iterations. The resulting factorial structure explained $57.3 \%$ of the variance and all of the factors exceeded Eigenvalue of 1. 
The first factor (named unobstructed play) includes purchase motivation related to being able to smoothly continue playing without obstructions or distractions: speeding times, avoiding repetition, reaching completion, continuing play, and protecting achievements. The second factor (named social interaction) includes purchase motivations related to social (self-)presentation and interaction: playing with friends, personalization, giving gifts, avoiding spam, and participating in a special event. The third factor (named competition) includes purchase motivation related to competition, becoming the best player and showing it to others: becoming the best, showing off achievements, and showing off to friends. The fourth factor (name economical rationale) includes purchase motivations related to economical rationale for purchases: reasonable pricing, special offers, supporting a good game and investing in a hobby (See Table 4).

As exceptions to factors formed from several items, the unlocking content and indulging the children motivations do not clearly load onto any of the factors. It is notable that unlocking content has much higher mean rating than others (only supporting a good game reaching close), suggesting that it is an important motivation in itself - relevant to any people who like the game and want more of it, regardless of why they like it. Perhaps, combined with the fact that the item loaded equally on factors 1 and 2 , the fact that the item is more vague on what the unlocked content could be (giving only a couple of examples of content types), therefore not discriminating between possible subcomponents, prevented it from forming a factor of its own. Moreover, indulging the children loads onto a factor of its own. This similarly suggests that there are no clearly identifiable type of in-game content that would be purchased for children, while at the same time purchasing content for children is distinguished as its own identifiable separate motivation. It is, however, connected to protecting achievements (.451) and special event 
participation (.425) which are almost as highly loaded onto the factor of "indulging the children" as they are on their primary factors.

Table 4. The purchase motivations EFA

\begin{tabular}{|c|c|c|c|c|c|}
\hline & $\begin{array}{l}1 \text { Unobstructed } \\
\text { play }\end{array}$ & $\begin{array}{l}2 \text { Social } \\
\text { interaction }\end{array}$ & $\begin{array}{l}3 \\
\text { Competition }\end{array}$ & $\begin{array}{l}4 \text { Economical } \\
\text { rationale }\end{array}$ & $\begin{array}{l}5 \text { Indulging the } \\
\text { children }\end{array}$ \\
\hline Speeding timers & .763 & -.182 & .133 & .141 & -.045 \\
\hline Avoiding repetition & .716 & -.002 & .202 & .159 & -.045 \\
\hline Reaching completion & .684 & .136 & .093 & -.058 & .345 \\
\hline Continuing play & .679 & .265 & -.003 & -.021 & .186 \\
\hline $\begin{array}{l}\text { Protecting } \\
\text { achievements }\end{array}$ & .474 & .347 & .245 & -.009 & .451 \\
\hline Playing with friends & .181 & .668 & .249 & .108 & -.101 \\
\hline Personalization & -.129 & .635 & .218 & .235 & .127 \\
\hline Giving gifts & -.172 & .595 & .194 & .189 & .136 \\
\hline Avoiding spam & .360 & .567 & -.045 & -.008 & -.009 \\
\hline $\begin{array}{l}\text { Participating in a } \\
\text { special event }\end{array}$ & .184 & .496 & .148 & .186 & .422 \\
\hline $\begin{array}{l}\text { Showing off } \\
\text { achievements }\end{array}$ & .048 & .244 & .818 & .121 & .134 \\
\hline $\begin{array}{l}\text { Showing off to } \\
\text { friends }\end{array}$ & .071 & .202 & .797 & .014 & .117 \\
\hline Becoming the best & .425 & .002 & .637 & .082 & -.158 \\
\hline Reasonable pricing & .132 & -.037 & -.018 & .745 & -.157 \\
\hline $\begin{array}{l}\text { Supporting a good } \\
\text { game }\end{array}$ & -.136 & .111 & .065 & .728 & .208 \\
\hline Special offers & .187 & .295 & .000 & .640 & .063 \\
\hline Investing in a hobby & .106 & .264 & .216 & .575 & .104 \\
\hline $\begin{array}{l}\text { Indulging the } \\
\text { children }\end{array}$ & .062 & -.022 & .021 & .088 & .796 \\
\hline Unlocking content & .395 & .368 & -.177 & .177 & -.151 \\
\hline$\%$ of variance & $15.4 \%$ & $12.7 \%$ & $11.0 \%$ & $10.9 \%$ & $7.3 \%$ \\
\hline
\end{tabular}




\begin{tabular}{|l|l|l|l|l|l|}
\hline Eigenvalue & 4.770 & 2.172 & 1.578 & 1.308 & 1.056 \\
\hline
\end{tabular}

\subsection{Confirmatory factor analysis}

Based on the results of the exploratory factor analyses, we conducted confirmatory factor analyses in order to investigate the convergent and discriminant validity of the factors. Moreover, we calculated the means and standard deviations per factor (Table 5). As indulging the children and unlocking content loaded onto their own factors, they were modelled as a singleitem constructs in CFA for comparison purposes.

As per convergent reliability, all composite reliability values exceed the recommended .7 (Fornell \& Larcker 1981). As per convergent validity, social (AVE 0.442) and economical (0.492) constructs do not exceed the recommended AVE value of .5. When investigating the item loadings closer in the CFA solution, we can notice that in the social construct all loadings fall between .666-.732, except for the avoiding spam item, which has a loading of only .504 . Similarly, for the economic rationale construct, reasonable pricing deviates the most from other items by having a loading of .581, whereas other items fall between $.681-.797$. It should be noted that the SEM factor analysis algorithm slightly differs from the one used in SPSS. Therefore, the loadings of different items can differ between the present analysis and the EFA in Step 2.3. However, for confirmatory analysis, the SEM analysis can be regarded as the more standard approach. By removing these two items from the model, AVEs of both constructs exceed the .5 threshold as well as the .7 threshold for the square root of the AVE. Otherwise CFA shows similar figures across the board. 
As per discriminant validity, no inter-correlation of constructs exceeds the square root of the AVE of either of those compared constructs (bolded figures on the diagonal are larger than any figure in the correlation matrix on the same row or column). Moreover, all items loaded most highly with the construct to which they were assigned. Therefore, we can conclude that discriminant validity is met (see e.g. Fornell \& Larcker 1981).

Table 5: Convergent validity and discriminant validity

\begin{tabular}{|l|l|l|l|l|l|l|l|l|l|l|}
\hline Construct & Mean & SD & AVE & CR & $\mathbf{1}$ & $\mathbf{2}$ & $\mathbf{3}$ & $\mathbf{4}$ & $\mathbf{5}$ & $\mathbf{6}$ \\
\hline $\mathbf{1}$ Unobstructed play & 2.643 & 1.502 & 0.521 & 0.844 & $\mathbf{0 . 7 2 2}$ & & & & & \\
\hline $\mathbf{2}$ Social interaction & 2.658 & 1.351 & 0.442 & 0.796 & 0.372 & $\mathbf{0 . 6 6 5}$ & & & & \\
\hline $\mathbf{3}$ Competition & 1.883 & 1.167 & 0.655 & 0.848 & 0.371 & 0.441 & $\mathbf{0 . 8 0 9}$ & & & \\
\hline 4 Economical reasoning & 4.035 & 1.531 & 0.492 & 0.793 & 0.252 & 0.480 & 0.272 & $\mathbf{0 . 7 0 1}$ & & \\
\hline 5 Indulging the children & 1.297 & 1.012 & 1.000 & 1.000 & 0.193 & 0.152 & 0.134 & 0.134 & $\mathbf{1 . 0 0 0}$ & \\
\hline 6 Unlocking content & 4.963 & 2.07 & 1.000 & 1.000 & 0.229 & 0.229 & 0.092 & 0.223 & 0.074 & $\mathbf{1 . 0 0 0}$ \\
\hline
\end{tabular}

\section{The relationship between reasons to purchase and the amount of}

\section{money spent on in-game content}

While the motivations to use money describe which reasons have been important to respondents when they have purchased in-game content, the means do not inform us about the relationship between the motivations and how much the players are spending money on in-game content. Therefore, we conducted a multiple regression analysis on how the purchase motivation constructs were associated with a latent variable on how much money players use via four items: 1) total money used on free-to-play games, 2) money spent on average per week on free-to-play games, 3) money used on the free-to-play game the respondent has played the most based on their self-reporting, and 4) money spent on average per week on the most played free-to-play. 
Respondents reported an integer to these questions on the survey. The validity and reliability of this latent variable were acceptable (AVE 0.635, CR 0.874). The two items that were deemed borderline acceptable in the last step (2.5.) were retained in the model. When conducting the following analysis without them, the results did not differ in any remarkable manner, and therefore, to ensure consistency with future studies that may employ this survey instrument, the entire instrument was used here.

The results (Table 6) reveal that purchase motivations of unobstructed play $\left(0.121^{* *}\right)$, social interaction $\left(0.100^{*}\right)$, and economical rationale $\left(0.268^{* * *}\right)$ were positively associated with how much the players spend money in free-to-play games.

Table 6: The relationship between purchase motivations and the use of money

\begin{tabular}{|l|l|l|l|l|}
\hline IV: In-game purchase activity $(\mathbf{R 2}=\mathbf{0 . 1 5 7})$ & Beta & CI95 low & CI95 high & $\mathbf{p}$ \\
\hline Unobstructed play & $0.121^{* *}$ & 0.018 & 0.234 & 0.029 \\
\hline Social interaction & $0.100^{*}$ & -0.000 & 0.200 & 0.053 \\
\hline Competition & 0.032 & -0.070 & 0.156 & 0.580 \\
\hline Economical rationale & $0.268^{* * *}$ & 0.191 & 0.353 & 0.000 \\
\hline Indulging the children & -0.047 & -0.132 & 0.043 & 0.300 \\
\hline Unlocking content & 0.014 & -0.052 & 0.075 & 0.671 \\
\hline$*=\mathrm{p}<0.1, * *=\mathrm{p}<0.05, * * *=\mathrm{p}<0.01$ & & & \\
\hline
\end{tabular}

\section{Discussion}

The results of the present study highlight that in games that employ the business model of selling in-game goods, the demand for those goods is, to a large extent, dictated by how the game is designed and by the rules that govern how the items function in relation to the game's rules. 
Therefore, developers can be seen to create value for the in-game products through a careful configuration of the interplay between the game and the products sold therein (e.g. see Alha et al. 2014; Hamari \& Lehdonvirta 2010: Hamari 2011; Hamari 2015; Hamari \& Järvinen 2011; Lin \& Sun 2011; Nieborg 2015; Prax 2013; Zagal et al. 2013) via various artificial limitations such as the intentional degradation of items, planned obsolescence, or a fear of losing content which has been gathered in the game (Hamari \& Lehdonvirta 2010; Hamari 2011). Therefore, it may not be surprising that this commodification of games has faced resistance from users and developers alike (Alha et al. 2014; Hamari 2015; Kimppa et al. 2016; Lin \& Sun 2011); both artificial obstacles (Hamari \& Lehdonvirta 2010; Hamari 2011; 2011; Lin \& Sun 2011) and the use of players as a form of commodity (Hamari \& Järvinen 2011; Nieborg 2015) belong to the repertoire of designs that aims at generating more revenue. These practices have raised interesting questions about the ethics of the game business (Alha et al. 2014; Kimppa et al. 2016; Prax 2013). Relatedly, past literature has found that the relationship between game enjoyment and willingness to purchase in-game goods is a complex matter (see e.g. Hamari 2015; Hamari \& Keronen 2016; Park \& Lee 2011), indicating that those players who wish to continue playing the game but find it less enjoyable (possibly because of the aforementioned artificial obstacles) are more willing to purchase in-game items. Therefore, developers are enticed to strike a balance between having a fun enough game to retain players, but inconvenient enough to entice more ingame purchases. In this manner, obstructing the playing process might hinder the experience for the majority while emphasizing gaining revenue from a small minority of high spenders instead of more equal division, which the developers have themselves called for (Alha et al. 2014). Indeed, a recent monetization report from game industry reveals that $48 \%$ of revenue is generated by $0,19 \%$ of player population in mobile free-to-play games (Swrve 2016), 
highlighting the role of the small paying minority. Findings of the present study corroborate these past observations: people indeed seem to use more money on in-game items in order to unobstruct play by, for example, speeding timers or by avoiding the loss of their achievements.

Social motivations have been deemed to be one of the main categories of motivations for purchases of in-game items and other virtual goods in general (Lehdonvirta 2009). Several studies have investigated the relationship between differing social aspects, such as social value (Shang et al. 2012), self-presentation (Kim et al. 2011; Kim et al. 2012), social influence (Guo \& Barnes 2011; Hamari 2015) and social presence (Animesh et al. 2011; Mäntymäki \& Riemer 2014; Shang 2012), status (Guo \& Barnes 2012) and virtual goods purchases. While these studies overall find that many of these latent social motivations have a positive association with purchases of virtual goods, in the present study we examined more concrete forms of social interaction within the game, such as playing with friends, personalizing an avatar and gift giving. Our findings corroborate the findings of prior studies on the social psychological aspects by showing that also the willingness to undertake social interaction was found the be positively associated with how much money the users use on in-game content. Social ties are a strong incentive to pay for in-game features, and this can manifest in various ways, for instance, by buying accelerators or boosters to keep up with friends' pace or to help the social group fare better. Helping others by sending gifts is a common game mechanic in social network games and sometimes such games monetize these reciprocal actions by offering in-app purchases of gifts (Lehdonvirta 2009; Paavilainen et al. 2016; Wohn 2014), strengthening relationships between players (Paavilainen et al. 2013). As customization factored with other social motivations, the visual alteration can be seen important especially for its social dimension, and is, therefore, more important in games where other players can easily see the customized elements. 
The results show that competition on average was reported to be rather unimportant as purchase motivation for in-game content. Moreover, it was not significantly associated with how much money players spend on in-game content. Overall, these findings indicate that while competition did emerge as its own category of reasons to purchase in-game goods, it was not significantly associated with increased use of money on in-game goods. As far as we know, competition has not been investigated as a determinant of in-game item purchases in prior quantitative studies. However, competition inherently connects to threads of prevailing discussion around the free-toplay business model (see e.g. Hamari \& Lehdonvirta 2010; Lin \& Sun 2011; Lehdonvirta 2009). Free-to-play games are often called as "pay-to-win", as in many games it is possible to use money to gain competitive advantage. Being able to spend real money in order to gain competitive advantage in a game has understandably been deemed unfair (See e.g. Alha et al. 2014; Kimppa et al. 2016; Lin \& Sun 2011). While the designs of the games may afford gaining competitive advantage, our results from the player perspective do not support the "pay-to-win"hypothesis in the sense that the pertaining motivations do not seem to increase how much players spend money on in-game items in our data set. Relatedly, game design professionals have indicated that pay-to-win monetization is a sign of a poorly implemented free-to-play game business model (Alha et al. 2014; Lin \& Sun 2011; Paavilainen et al. 2016).

On average economical rationale was rated as the most important reason for in-game purchases overall, and it was most strongly associated with how much players spend on in-game content out of the purchase motivation dimensions established within the present study. Prior literature on virtual good purchases has commonly investigated economic motivations operationalized as monetary value (e.g. Chou \& Kimsuwan 2013; Kim 2012; Liue \& Shie 2014; Park \& Lee 2011), i.e. the respondent's perception whether the in-game items offer value for money. In the present 
study, we measured a more diverse set of variables regarding the economic rationale related to purchasing in-game items: price, special offers and willingness to support the developer of the game. However, factor analyses revealed that these aspects converged onto a single factornamed here economical rationale as it consists of more than just the perception of the relationship of value versus cost. It is somewhat surprising that a motivation that is almost altruistic - wanting to support the game developers - is so strongly associated with attempting to capitalize on good deals, which can be considered more of an individualistic, rational reasoning. Another possible interpretation is, however, that reasonable prices may awaken perceptions of good will and reciprocity that also make consumers willing to return this fairness.

In-game purchases have generally faced a large backlash from the player community because of, for example, the above-mentioned "pay-to-win" issue. Therefore, there are many emotion-based attitudinal factors surrounding in-game purchases that may diminish the overall willingness to make them (Lin \& Sun 2011; Hamari 2015). However, as our results here indicate, players that deem economical aspects as important reasons for purchases may approach purchase decisions with a more rational mindset, and therefore, might be less limited by attitudinal or ideological resistance, and further be willing to spend more money. Therefore, while the in-game content is usually in the focus, the price level and timely special offers should not be neglected. As supporting the game or the game company seems to be one of the criteria for spending money, the handling of public relations and customer service becomes meaningful as well. Furthermore, game professionals have also highlighted the importance of taking care of the social communities in free-to-play games (Alha et al. 2014). 
Purchasing in-game content for children emerged as a pertinent reason to purchase in-game content in our pre-study for the questionnaire development, and therefore, it was added as one of the purchase reasons in the final questionnaire. This item loaded onto its own factor (Indulging the children) with no other purchase reasons. Not surprisingly, however, participating in a special event and protecting achievements were most highly associated motivations with the factor. It could be that a parent is more willing to spend money on her child's game when not doing so might mean missing seasonal content or rare events, or losing something already achieved - which might seem like an important reason for the child because of fear of missing out. While there are indications that parents have motivation to use money on their children's games especially when there is a danger to lose something or skip content, special care has to be taken when implementing purchases in games targeted for children. For instance, attention should be paid to assuring that children do not accidentally use money without their parents' acknowledgement (Alha et al. 2014). On average, it can be said that within our data set nearly no one of the respondents reported having purchased in-game content for (their) kids nor was this motivation associated with how much money is being spent on in-game content. However, this is hardly surprising given the age distribution in our data set.

While Unlocking content on average was reported as the highest occurring motivation for purchases, it was not significantly associated with the volume of money being used. This may indicate that, unlocking content is equally important for both small and big spenders. Alternatively, the phrasing of the statement ("I wanted to open new playable content (e.g. levels, characters, cards...)") is quite extensive and has likely caught several types of motivations connected to content unlocking, explaining why it did not correlate highly with any other specific dimension. Therefore, unlocking content is slightly related to several more precise 
purchase motivations. There are some limitations to our research. Even though the motivations were acquired through careful triangulation, it is likely that not all possible purchase motivations are covered here. This also becomes apparent in the low R2 in the regression analysis.

Free-to-play is a large phenomenon having spread to various genres and platforms and using different kinds of monetization mechanics. Therefore, it is crucial to see that some of the motivations might be important in only certain types of games, while other motivations could be missing from some games altogether. For instance, many of the currently successful free-to-play games have not included the above-mentioned waiting times, allowing the player to play as long as she wishes, and trying to get the revenue through other monetization mechanics. This is especially typical outside the mobile free-to-play games, in games such as Team Fortress 2 and World of Tanks. It is worth mentioning that these games have also reported conversion rates of 20-30 percent from non-paying to paying players. In comparison, mobile free-to-play games have been reported to have a paying player portion of as low as 1.5 percent (Bishop 2011; Martin 2012; Swrve 2014). The higher conversion rate can be seen as an improvement and a favorable direction from the perspective of the developers as well, as the model of small minority of high spenders paying for the most of the income is one of the ethical concerns in free-to-play games (Alha et al. 2014). These games have a strong focus on sociability, and they monetize the games by cosmetic or competitive items. While this has been rarer especially in commercially successful mobile free-to-play games, the game company Blizzard has been able to bring this model to mobile with their cross-platform game, Hearthstone (Alha et al. 2016). Free-to-play game industry is an extensive one, including games for different platforms and in several genres, and offering various types of experiences (Paavilainen et al. 2015a). Therefore, it would be interesting to study how purchase motivations differ in different types of free-to-play games. 
Moreover, games garner a varying audience, and therefore, it would be interesting to investigate how purchase motivations may differ along different playing orientations (Hamari \& Tuunainen 2014; Yee 2006) as well as the demographics of players (see e.g. Williams, Yee \& Caplan 2008).

\section{Conclusion}

In this paper, we set out to develop a measurement instrument for concrete motivations to buy ingame content. Firstly, we composed a measurement instrument for identifying between different motivations and reasons to purchase in-game content by triangulating from top-grossing games, existing research, and from discussions with game industry specialists. These reasons were operationalized into a survey which was further administered to free-to-play game players $(\mathrm{N}=519)$ that had purchased in-game content. Based on analyses of the gathered data, the purchasing reasons converged into six dimensions: 1) Unobstructed play, 2) Social interaction, 3) Competition, 4) Economical rationale, 5) Indulging children, and 6) Unlocking content. The motivations for purchases can be approached from many directions. While previous research on the purchase motivations in free-to-play games has concentrated more on abstract psychological factors, this study sheds light on the more concrete rationale behind the purchases. The dimensions will provide a useful tool for future research. From the design perspective, the motivation categories established in the present study is a contribution of its own. While the game design literature has discussed different types of in-game content and strategies for implementing them in games (Fields \& Cotton 2012; Luton 2013), the presented list of purchase motivations provides a more detailed perspective for the developers to approach in-game content design from the user-centered design perspective. 
Secondly, this study investigated how these purchase motivations were associated with how much money players use on in-game content. The results revealed that purchase motivations of unobstructed play, social interaction, and economical rationale were positively associated with how much money the players spend on in-game content, whereas competition, indulging the children, and unlocking content were not significantly associated.

\section{References}

Alha, K., Koskinen, E., Paavilainen, J., \& Hamari, J. (2016). Critical Acclaim and Commercial Success in Mobile Free-to-Play Games. In Proceedings of DiGRA FDG Conference, Dundee, Scotland, 1-6 August, 2016.

Alha, K., Koskinen, E., Paavilainen, J., Hamari, J. \& Kinnunen, J. (2014). Free-to-Play Games: Professionals' Perspectives. In Proceedings of Nordic Digra 2014, Gotland, Sweden, May 29, 2014.

Alves, R. T., \& Roque, L. (2007). Because players pay: The business model influence on mmog design. Proceedings of DiGRA 2007, 658-663.

Animesh, A., Pinsonneault, A., Yang, S.-B. \& Oh, W. (2011). An odyssey into virtual worlds: Exploring the impacts of technological and spatial environments on intention to purchase virtual products. MIS Quarterly, 35(3), pp. 789-810.

Bishop, T. (2011). How Valve experiments with the economics of video games. In GeekWire. http://www.geekwire.com/2011/experiments-video-game-economics-valves-gabe-newell/ 
Brockmann, T., Stieglitz, S. \& Cvetkovic, A. (2015) Prevalent Business Models for the Apple App Store. Wirtschaftsinformatik Proceedings 2015. Paper 81.

Cha, J. (2011). Exploring the internet as a unique shopping channel to sell both real and virtual items: A comparison of factors affecting purchase intention and consumer characteristics. Journal of Electronic Commerce Research, 12(2), pp. 115-132.

Chou, C.-M. \& Kimsuwan A. (2013) Factors affecting purchase intention of online game prepayment card - Evidence from Thailand. Journal of Internet Banking and Commerce, vol. 18, no. 3, pp. 1-13.

Cleghorn, J., \& Griffiths, M. (2015). Why Do Gamers Buy 'Virtual Assets'? An Insight in to the Psychology Behind Purchase Behaviour. Digital Education Review, (27), 85-104.

Domina, T., Lee, S.-E. \& MacGillivray, M. (2012). Understanding factors affecting consumer intention to shop in a virtual world. Journal of Retailing and Consumer Services, 19(6), pp. 613620.

Fields, T. \& Cotton, B. (2012). Social Game Design: Monetization Methods and Mechanics. Walthman, MA: Morgan Kaufmann

Fornell, C. \& Larcker, D.F. (1981). Evaluating structural equation models with unobservable variables and measurement error. Journal of Marketing Research 18 (1), 39-50. 
Evans, E. (2015). The economics of free freemium games, branding and the impatience economy. Convergence: The International Journal of Research into New Media Technologies, pp. 1-18.

Gao, J. (2014). An empirical research on consumers' purchasing behavior of virtual products in SNS. Research Journal of Applied Sciences, Engineering and Technology, 7(7), pp. 1279-1286.

Guo, Y. \& Barnes, S. (2011). Purchase behavior in virtual worlds: An emprical investigation in Second Life. Information \& Management, 48(7), pp. 303-312.

Guo, Y. \& Barnes, S. (2012). Explaining purchasing behavior within World of Warcraft. Journal of Computer Information Systems, 52(3), pp. 18-30.

Hamari, J. (2011). Perspectives from behavioral economics to analyzing game design patterns: loss aversion in social games. In Proceedings of CHI'2011 (Social games workshop), Vancouver, Canada, May 7-12, 2011. Social games workshop.

Hamari, J. (2010). Virtual goods sales: new requirements for business modelling? Master's thesis. University of Jyväskylä.

Hamari, J. (2015). Why do people buy virtual goods? Attitude towards virtual good purchases versus game enjoyment. International Journal of Information Management, 35(3), 299-308.

Hamari, J., \& Järvinen, A. (2011). Building Customer Relationship through Game Mechanics in Social Games. In M. Cruz-Cunha, V. Carvalho \& P. Tavares (Eds.) Business, Technological and 
Social Dimensions of Computer Games: Multidisciplinary Developments (pp. 348-365).

Hershey, PA: IGI Global.

Hamari, J., \& Keronen, L. (2016). Why do people buy virtual goods? A literature review. In Proceedings of the 49th Annual Hawaii International Conference on System Sciences (HICSS), Hawaii, USA, January 5-8, 2016.

Hamari, J., Keronen, L., \& Alha, K. (2015). Why do people play games? A review of studies on adoption and use. In proceedings of the 48th Annual Hawaii International Conference on System Sciences (HICSS), Hawaii, USA, January 5-8, 2015.

Hamari, J., \& Lehdonvirta, V. (2010). Game design as marketing: How game mechanics create demand for virtual goods. International Journal of Business Science \& Applied Management, 5(1), 14-29.

Hamari, J., \& Tuunanen, J. (2014). Player Types: A Meta-synthesis. Transactions of the Digital Games Research Association, 1(2), 29-53.

Han, B. \& Windsor, J. (2013). An investigation of the smartphone user's in-game purchase intention. International Journal of Mobile Communications, 11(6), pp. 617-635.

Hanner, N., \& Zarnekow, R. (2015). Purchasing behavior in free to play games: Concepts and empirical validation. Proceedings of the Annual Hawaii International Conference on System Sciences, , 2015-March 3326-3335. doi: 10.1109/HICSS.2015.401 
Harviainen, J.T. \& Hamari, J. (2015). Seek, Share, or Withhold: Information Trading in MMORPGs. Journal of Documentation, 71(6), 1119-1134.

Huang, E. (2012). Online experiences and virtual goods purchase intention. Internet Research, 22(3), pp. 252-274.

Jankowski, J., Bródka, P., \& Hamari, J. (2016). A picture is worth a thousand words: an empirical study on the influence of content visibility on diffusion processes within a virtual world. Behavior \& Information Technology. DOI: 10.1080/0144929X.2016.1212932

Kaburuan, E. R., Chen, C.-H. \& Jeng, T.-S. (2009). Identifying users' behavior purchasing virtual items. The 9th International Conference on Electronic Business, Macau, November 30 December 4, 2009, pp. 250-256.

Kallio, K. P., Mäyrä, F., \& Kaipainen, K. (2010). At least nine ways to play: approaching game mentalities. Games \& Culture. http://doi.org/10.1177/1555412010391089

Kim, B. (2012). Understanding key factors of users' intentions to repurchase and recommend digital items in social virtual worlds. Cyberpsychology, Behavior, and Social Networking, 15(10), pp. 543-550.

Kim, H.-W., Chan, H. C. and Kankahalli, A. (2012) What motivates people to purchase digital items on virtual community websites? The desire for online self-presentation, Information Systems Research 23(4): 1232-1245. 
Kim, H.-W., Gupta, S. and Koh, J. (2011) Investigating the intention to purchase digital items in social networking communities: A customer value perspective, Information \& Management 48(6): 228-234.

Kimppa, K. K. Heimo, O. I. and Harviainen, T. J. (2016) First dose is always freemium. ACM SIGCAS Computers and Society - Special Issue on Ethicomp 45(3): 132-137.

Lee, J., Lee, M. \& Choi, I. H. (2012). Social network games uncovered: Motivations and their attitudinal nad behavioral outcomes. Cyberpsychology, Behavior, and Social Networking, 15(12), pp. 643-648.

Lee, Y.-H. \& Wohn, D. Y. (2012). Are there cultural differences in how we play? Examining cultural effects on playing social network games. Computers in Human Behavior, 28(4), pp. 1307-1314.

Lehdonvirta, V. (2009). Virtual item sales as a revenue model: identifying attributes that drive purchase decisions. Electronic Commerce Research, 9(1-2), 97-113.

Lin, H. \& Sun, T.-C. (2011). Cash trade in free-to-play online games. Games and Culture, 6(3), pp. $270-287$.

Liu, H.-J. \& Shiue, Y.-C. (2014). Influence of facebook game players' behavior on flow and purchase intention. Social Behavior and Personality, 42(1), pp. 125-134. 
Luo, M. M., Chen, J.-S., Ching, R. K. \& Liu, C.-C. (2011). An examination of the effects of virtual experiential marketing on online customer intentions and loyalty. The Service Industries Journal, 31(13), pp. 2163-2191.

Luton, W. (2013). Free2Play: Making Money From Games You Give Away. San Fransisco, CA: New Riders.

Martin, M. (2012). World of Tanks monthly revs hitting "double digit" millions. In GamesIndustry.biz. http://www.gamesindustry.biz/articles/2012-03-19-world-of-tanks-monthlyprofits-hitting-double-digit-millions

Mäntymäki, M., \& Riemer, K. (2014) "Digital natives in social virtual worlds: A multi-method study of gratifications and social influences in Habbo Hotel. International Journal of Information Management, 34 (2), 210-220.

Nieborg, D. B. (2015). Crushing Candy: The Free-to-Play Game in Its Connective Commodity Form. Social Media + Society, 1(2), pp. 1-12.

Oh, G. \& Ryu, T. (2007). Game Design on Item-selling Based Payment Model in Korean Online Games. In Proceedings of DiGRA 2007: Situated Play (pp. 650-657). Tokyo, Japan

Paavilainen, J. (2016). Design Paradigms and Principles of Free-to-Play Games: A Developer Interview Study. In Proceedings of DiGRA FDG Conference, Dundee, Scotland, 1-6 August, 2016. 
Paavilainen, J., Hamari, J., Stenros, J., \& Kinnunen, J. (2013). Social Network Games: Players' Perspectives. Simulation \& Gaming, 44(6), 794-820.

Paavilainen, J., Koskinen, E., Korhonen, H., \& Alha, K. (2015a). Exploring Playful Experiences in Social Network Games. In Proceedings of DiGRA Conference, Lüneburg, Germany, 14-17 May 2015.

Paavilainen, J., Alha, K. \& Korhonen, H. (2015b). Domain-Specific Playability Problems in Social Network Games. International Journal of Arts \& Technology, 8(4).

Paavilainen, J., Alha, K. \& Korhonen, H. (2016). Review of Social Features in Social Network Games. In Proceedings of DiGRA FDG Conference, Dundee, Scotland, 1-6 August, 2016.Park, B.-W. \& Lee, K. C. (2011). Exploring the value of purchasing online game items. Computers in Human Behavior, 27(6), pp. 2178-2185.

Prax, P. (2013). Game Design and Business Model: An Analysis of Diablo 3. In Proceedings of DiGRA 2013 Conference. Atlanta, USA.

Ryan, R. M., Rigby, C. S., \& Przybylski, A. K. (2006). The Motivational Pull of Video Games: A Self-Determination Theory Approach. Motivation and Emotion, 30(4), 344-360.

Shang, R. A., Chen, Y. C., \& Huang, S. C. (2012). A private versus a public space: Anonymity and buying decorative symbolic goods for avatars in a virtual world. Computers in Human Behavior, 28(6), 2227-2235. 
Sherry, J. L., Lucas, K., Greenberg, B. S., \& Lachlan, K. (2006). Video game uses and gratifications as predictors of use and game preference. In P. Vorderer \& J. Bryant (Eds.), Playing video games: Motives, responses, and consequences (pp. 213-224). Mahwah, NJ: Lawrence Erlbaum Associates.

Swrve (2014). The Swrve Monetization Report.

Tyni, H., Sotamaa, O., \& Toivonen, S. (2011). Howdy Pardner!: On free-to-play, sociability and rhythm design in FrontierVille. Mindtrek 2011, pp. 22-29.

Wang, W.-T. \& Chang, W.-H. (2013). The integration of the expectancy disconfirmation and symbolic consumption theories: A case of virtual product consumption. 46th Hawaii International Conference on System Sciences, pp. 2949-2956.

Wang, W.-T. \& Chang, W.-H. (2014). A study of virtual product consumption from the expectancy disconfirmation and symbolic consumption perspectives. Information Systems Frontiers, 16(5), pp. 887-908.

Williams, D., Yee, N., \& Caplan, S. E. (2008). Who plays, how much, and why? Debunking the stereotypical gamer profile. Journal of Computer-Mediated Communication, 13(4), 993-1018.

Wohn, D. Y. (2014). Spending real money: Purchasing patterns of virtual goods in an online social game. Proceedings of the 32nd annual ACM conference on Human factors in computing systems, pp. 3359-3368. 
Yee, N. (2006). Motivations for play in online games. CyberPsychology \& behavior, 9(6), 772775.

Zagal, J.P., Björk, S. \& Lewis, C. (2013) Dark Patterns in the Design of Games. Proceedings of the 8th International Conference on the Foundations of Digital Games, FDG 2013, Chania, Crete, Greece, May 14-17, 2013. 